\title{
Effect of Weather Indices on Late Blight of Potato and Its Management in Northern District of West Bengal, India
}

\author{
S. Hembram ${ }^{1}$, R. Patsa ${ }^{2}$, S. Baskey ${ }^{3 *}$ and M. Hansda ${ }^{4}$ \\ ${ }^{1}$ Regional Research Station, Terai Zone, ${ }^{2}$ Department of Plant Pathology, Uttar Banga Krishi \\ Viswavidyalaya, Cooch Behar-736165, West Bengal, India \\ ${ }^{3}$ Regional Research Station, Hill Zone, ${ }^{4}$ AICW\&BIP, Uttar Banga Krishi Viswavidyalaya, \\ Cooch Behar, West Bengal, India \\ *Corresponding author
}

\section{A B S T R A C T}

Late blight caused by Phytophthora infestans (Mont.) de Bary has historically been a most serious disease of potatoes worldwide, including India. Due to differences in prevailing

\section{Keywords}

Phytophthora infestans, Temperature, Disease incidence and tuber yield

Article Info

Accepted:

12 August 2018

Available Online:

10 September 2018 weather conditions, its severity varies from region to region. when tuber are planted first fort night of October disease initiated within 59 days, and there after the period for disease initiation decreases. It was observed that number of days to initiate late blight symptom on potato was an inverse function $(\mathrm{Y}=\mathrm{a}+\mathrm{bx}-1)$ of average minimum temperature from sowing and R2 values (0.81) of the equation were statistically significant at $1 \%$ level of significance. The results also revealed that in respect of per cent incidence of the disease (at 49 days after first appearance of symptoms) lowest disease was recorded in case of treatment T3 and total tuber yield i.e., in T3 it was 15.4 to 24.6 t/ha respectively followed by $\mathrm{T} 1$ and $\mathrm{T} 2$ as compared to control treatment (T5) where per cent disease incidence was 89.70 to $97.14 \%$ and total tuber yield was 8.68 to 14.0 t/ha. B Not only that the farmers in a locality should apply fungicide at the same time and the whole plant should be sprayed till run off.

\section{Introduction}

Late blight caused by Phytophthora infestans (Mont.) de Bary is one of the most dreaded diseases of potato worldwide, including India and cause significant loss in production. In West Bengal it was first observed in Darjeeling district in 1883. In the plains, it was first noticed during 1898-1900 in
Hooghly district of West Bengal. Today, late blight is a recurring feature in plains of West Bengal. It occurs in mild to moderate form every year but occasionally assumes epiphytotic proportions. Yield losses in the plains have been estimated around 10-75\% (Dutta, 1979). Due to differences in prevailing weather conditions, its severity varies from region to region. 
The pathogen is highly variable and adapt to the newly bred varieties and fungicides. Region wise economic importance of late blight shows that the disease takes highest toll of potato in Sub-Saharan Africa (44\% crop losses) followed by South-East Asia (35\%) (CIP, 1997). Information on various aspects of late blight has been reviewed by different workers (Fry, 2008; Cooke et al., 2011; Lozoya-Saldana, 2011). Hence, the only option left is the use of need based effective fungicides for the management of late blight of potato (Singh and Bhat, 2003). Though there are several effective fungicides available in the market for late blight management but the farmers in West Bengal still become helpless when the late blight appears in epiphytotic form. This is mainly due to lack of proper spray schedule for management of the disease. The management of this devastating disease depends on regular application of fungicides at short intervals throughout the growing season resulting in health and environment hazards.

However, timely forecasting of the disease may result in lesser application of fungicides with effective management of the disease. Due to differences in prevailing weather conditions, its severity varies from region to region. Forecasting of the disease can greatly help in managing this disease thereby lowering crop losses. Van Everdingen (1926) for the first time developed decision rules for predicting late blight in Holland. Since then these rules have been modified by various workers (Johannes, 1953; Wallin and Hoyman, 1954) to suit to their conditions. In India, Singh et al., (2000) developed a computerized forecast model (JHULSACAST) for western Uttar Pradesh using hourly temperature, relative humidity (\%) and daily precipitation ( $\mathrm{mm}$ ) as input parameters. However, this model is location specific and needs to be calibrated for different agro-climatic conditions. Since then the model has been calibrated for predicting late blight appearance in Punjab (Arora et al., 2012) and Tarai region of Uttarakhand (Pundhir et al., 2014). In present investigation, different weather variables and fungicidal chemicals are studied for predicting late blight in North Bengal and developed effective spray scheduled for management of the disease.

\section{Materials and Methods}

The experiment was conducted at Agricultural Farm, Pundibari, UBKV, West Bengal (2639 $\mathrm{N}$ Latitude, $89^{\circ} 39^{\circ} \mathrm{E}$ Longitude and $50 \mathrm{~m}$ amsl) during 2015-16 crop seasons when there was severe incidence of late blight in the state. Five different date of planting was done $(16.10 .15,28.10 .15,16.11 .15,28.11 .15$ and 15.12.15). The variety viz. Kufri Jyoti received from Directorate of Farm, UBKV were used for this experiment. The crops are planted in randomized block design with 4 replications and 5 treatments at spacing of $60 \mathrm{~cm} \mathrm{X} 30 \mathrm{~cm}$ in a plot size of $3 \mathrm{~m} \mathrm{X} 3 \mathrm{~m}$.

Weather parameters (temperature, relative humidity and rainfall) were collected from the automatic weather station installed at AMFU, Cooch Behar Centre, UBKV, Pundibari, West Bengal and converted into the required format. The temperature and relative humidity data were computed on hourly basis whereas rainfall was computed on daily basis and these parameters were interpolated with the actual date of disease appearance (Fig. 1).

Regular monitoring for the date of disease onset and subsequent symptom development of late blight was recorded during early morning. Once the initial late blight symptoms were observed on the plant in the field, the dead areas appear at the tip or margin of the leaves and spread downward and inward. Decaying leaves emit offensive odour. In present day condition, stem infection is also very common, where dark brown lesions 
appeared on the stem or on the branches and the whole plant die within few days. The sign of tuber infection is brown to purple discoloration of the skin followed by a brown not which extends to about half an inch below the surface of the tubers.

The nature of the spread of the disease was studied through visual observation from the initiation of the disease at seven days interval till 49 days after first appearance of symptoms. The disease was quantified using disease grading 0-9 scale suggested by McKinney (1923) where, $0=$ Healthy Leaf, 1 $=<1 \%$ area of leaf infected, $3=1-10 \%$ area of leaf infected, $5=11-25 \%$ area of leaf infected, $7=26-50 \%$ area of leaf infected, and $9=$ more than $50 \%$ area of leaf infected.

The percent disease intensity (PDI) was calculated as given below (Wheeler, 1969).

$$
\mathrm{PDI}=\frac{\text { Total sum of numerical ratings }}{\text { Number ofleaves observed } \mathrm{x} \text { maximum disease ratings }} \times 100
$$

For this purpose, five plants were selected randomly from each plot and observations were taken from late blight infected leaves up to 49 days after first appearance of symptoms at every 7 days interval.

For all the treatments except control mancozeb @ $0.25 \%$ was applied as prophylactic spray (just at the time of canopy closure). Thereafter, all other sprays followed it in different treatments which were as follows:

$\mathrm{T} 1=$ Cymoxanil + mancozeb @ 0.3\% at the onset of the disease and 10 days after $1^{\text {st }}$ application followed by mancozeb @ 0.25\% seven days after the last application of systemic fungicide.

T2 = Dithiocarbamate + mancozeb @0.3\% at the onset of the disease and 10 days after $1^{\text {st }}$ application followed by mancozeb @ 0.25\% seven days after the last application of dithiocarbamate + mancozeb.

$\mathrm{T} 3=$ Ametoctradin + Dimethomorph @ 0.3\% at the onset of the disease and 10 days after $1^{\text {st }}$ application followed by mancozeb @ 0.25\% seven days after the last application of systemic fungicide.

T4 = Fenamidon + mancozeb @ 0.25\% at the onset of the disease and 10 days after $1^{\text {st }}$ application followed by mancozeb @ 0.25\% seven days after the last application of systemic fungicide.

T5 $=$ Control (without any spray)

\section{Results and Discussion}

\section{Relationship between times required for disease initiation and weather parameter}

The study was conducted in the experimental farm, Pundibari, UBKV. The seed tuber of potato were planted at five different dates $(16.10 .15,28.10 .15,16.11 .15,28.11 .15$ and 15.12.15) during rabi season at fifteen days intervals.

The crop was maintained according to the standard management practices. Five plant have been selected randomly from the each plot and observed regularly for disease initiation and it was observed that disease initiated within 59 days, when tuber are planted first fort night of October and there after the period for disease initiation decreases and lowest time required twenty three days observed during $15^{\text {th }}$ December'15 sowing date. It was observed that number of days to initiate late blight symptom on potato was an inverse function $(\mathrm{Y}=\mathrm{a}+\mathrm{bx}-1)$ of average minimum temperature from sowing and R2 values of the equation were statistically significant at $1 \%$ level of significance (Fig. 2). 
Table.1 Scheduling of fungicide application for the management of late blight of potato

\begin{tabular}{|c|c|c|c|c|c|c|c|c|c|}
\hline \multirow[t]{2}{*}{ Date of Sowing (DOS) } & \multirow[t]{2}{*}{ Treatment } & \multicolumn{8}{|c|}{ Percent incidence of late blight at different interval (days after first appearance of symptoms) } \\
\hline & & 7 & 14 & 21 & 28 & 35 & 42 & 49 & Yield (t/ha) \\
\hline \multirow[t]{5}{*}{16.10 .15} & $\mathrm{~T} 1$ & 0.0 & 0.0 & $4.02(11.55)$ & $7.82(16.24)$ & $9.92(18.33)$ & $12.62(20.77)$ & $14.50(22.38)$ & $0.00(23.33)$ \\
\hline & $\mathrm{T} 2$ & 0.0 & 0.0 & $4.47(12.18)$ & $8.05(16.45)$ & $10.49(18.88)$ & $13.15(21.25)$ & $14.92(22.71)$ & $0.00(20.67)$ \\
\hline & $\mathrm{T} 3$ & 0.0 & 0.0 & $4.46(12.16)$ & $6.24(14.42)$ & $12.30(20.51)$ & $13.18(21.26)$ & $13.99(21.96)$ & 4.46 (18.69) \\
\hline & $\mathrm{T} 4$ & 0.0 & $5.19(13.16)$ & $8.49(16.93)$ & $10.21(18.61)$ & $12.11(20.35)$ & $14.76(22.58)$ & $17.15(24.46)$ & $5.19(16.00)$ \\
\hline & $\mathrm{T} 5$ & $9.50(17.93)$ & $26.77(31.15)$ & $32.57(34.79)$ & $39.24(38.79)$ & $60.56(51.10)$ & $75.72(60.49)$ & $89.70(71.33)$ & $9.50(14.67)$ \\
\hline \multirow[t]{5}{*}{28.10 .15} & $\mathrm{~T} 1$ & 0.0 & 0.0 & $4.51(12.17)$ & $8.52(16.96)$ & $10.80(19.14)$ & $13.32(21.39)$ & $15.24(22.96)$ & $4.51(22.67)$ \\
\hline & $\mathrm{T} 2$ & 0.0 & 0.0 & $5.68(13.76)$ & $9.29(17.74)$ & $11.90(20.18)$ & $14.52(22.39)$ & $15.46(23.15)$ & $5.68(20.61)$ \\
\hline & $\mathrm{T} 3$ & 0.0 & 0.0 & $4.47(12.13)$ & $6.67(14.95)$ & $12.06(20.31)$ & $12.99(21.11)$ & $13.68(21.70)$ & $4.47(19.34)$ \\
\hline & $\mathrm{T} 4$ & 0.0 & $4.43(12.13)$ & $8.44(16.87)$ & $11.01(20.04)$ & $12.91(21.04)$ & $15.52(23.20)$ & $17.97(25.07)$ & $4.43(16.69)$ \\
\hline & $\mathrm{T} 5$ & $12.51(20.69)$ & $28.57(32.31)$ & $36.47(37.15)$ & $42.52(40.70)$ & $63.70(52.95)$ & $77.80(61.90)$ & $92.95(74.66)$ & $12.51(14.01)$ \\
\hline \multirow[t]{5}{*}{16.11 .15} & $\mathrm{~T} 1$ & 0.0 & 0.0 & $6.17(14.35)$ & $9.40(17.85)$ & $12.06(20.32)$ & $14.41(22.30)$ & $16.31(23.82)$ & $6.17(24.60)$ \\
\hline & $\mathrm{T} 2$ & 0.0 & 0.0 & $8.05(16.47)$ & $10.86(19.19)$ & $13.36(21.43)$ & $14.98(22.76)$ & $16.53(23.98)$ & $8.05(22.01)$ \\
\hline & $\mathrm{T} 3$ & 0.0 & 0.0 & $5.21(13.18)$ & $7.45(15.81)$ & $13.07(21.18)$ & $14.11(22.05)$ & $14.78(22.60)$ & $5.21(20.00)$ \\
\hline & $\mathrm{T} 4$ & 0.0 & $5.72(13.82)$ & $9.77(18.18)$ & $12.22(20.45)$ & $13.96(21.93)$ & $16.77(24.17)$ & $19.06(25.88)$ & $5.72(17.41)$ \\
\hline & T5 & $15.89(23.49)$ & $31.22(33.96)$ & $39.18(38.75)$ & $45.40(42.36)$ & $66.54(54.66)$ & $82.00(64.90)$ & $95.75(78.18)$ & $15.89(15.40)$ \\
\hline \multirow[t]{5}{*}{28.11 .15} & $\mathrm{~T} 1$ & 0.0 & 0.0 & $6.63(14.80)$ & $10.15(18.52)$ & $12.68(20.81)$ & $15.03(22.80)$ & $16.50(23.96)$ & $6.63(21.34)$ \\
\hline & $\mathrm{T} 2$ & 0.0 & 0.0 & $6.38(14.55)$ & $10.09(18.49)$ & $12.32(20.52)$ & $15.46(23.15)$ & $15.89(23.49)$ & $6.38(20.00)$ \\
\hline & $\mathrm{T} 3$ & 0.0 & 0.0 & $6.12(14.29)$ & $8.29(16.72)$ & $13.78(21.77)$ & $14.76(22.60)$ & $15.49(23.17)$ & $6.12(18.00)$ \\
\hline & $\mathrm{T} 4$ & 0 & $6.81(15.11)$ & $10.75(19.11)$ & $12.74(20.91)$ & $14.60(22.45)$ & $17.10(24.42)$ & $19.54(26.23)$ & $6.81(15.50)$ \\
\hline & $\mathrm{T} 5$ & $15.95(23.52)$ & $31.76(34.30)$ & $36.31(37.05)$ & $46.22(42.83)$ & $67.86(55.46)$ & $79.70(63.24)$ & $95.95(78.42)$ & $15.95(12.69)$ \\
\hline \multirow[t]{5}{*}{15.12 .15} & $\mathrm{~T} 1$ & 0.0 & 0.0 & $6.77(15.07)$ & $8.90(17.33)$ & $11.69(19.97)$ & $15.50(23.19)$ & $16.94(24.28)$ & $6.77(14.00)$ \\
\hline & $\mathrm{T} 2$ & 0.0 & 0.0 & $8.48(16.92)$ & $11.52(19.82)$ & $12.84(20.99)$ & $15.70(23.34)$ & $17.31(24.57)$ & $8.48(13.33)$ \\
\hline & $\mathrm{T} 3$ & 0.0 & 0.0 & $6.57(14.83)$ & $8.61(17.06)$ & $14.14(22.08)$ & $15.08(22.84)$ & $15.78(23.40)$ & $6.57(12.66)$ \\
\hline & $\mathrm{T} 4$ & 0.0 & $5.86(13.96)$ & $10.75(19.07)$ & $13.01(21.12)$ & $14.87(22.67)$ & $17.59(24.79)$ & $20.12(26.65)$ & $5.86(10.62)$ \\
\hline & T5 & $16.16(23.70)$ & $32.34(34.65)$ & $40.55(39.55)$ & $46.86(43.20)$ & $68.01(55.56)$ & $82.91(65.58)$ & $97.14(80.60)$ & $16.16(8.68)$ \\
\hline \multicolumn{10}{|l|}{ SEm \pm} \\
\hline DOS & & 0.11 & 0.16 & 0.28 & 0.24 & 0.22 & 0.20 & 0.26 & 0.27 \\
\hline Treatment & & 0.11 & 0.16 & 0.28 & 0.24 & 0.22 & 0.20 & 0.26 & 0.27 \\
\hline Interaction \# & & 0.26 & 0.50 & 0.63 & 0.53 & 0.49 & 0.45 & 0.57 & 0.59 \\
\hline \multicolumn{10}{|l|}{ CD $(5 \%)$} \\
\hline DOS & & 0.32 & 0.44 & 0.80 & 0.67 & 0.62 & 0.57 & 0.72 & 0.75 \\
\hline Treatment & & 0.32 & 0.44 & 0.80 & 0.67 & 0.62 & 0.57 & 0.72 & 0.75 \\
\hline Interaction \# & & 0.72 & 0.99 & 1.78 & 1.49 & 1.38 & 1.28 & 1.61 & 1.67 \\
\hline
\end{tabular}

*Figures in the parenthesis are transformed angular values. \# Interaction between date of sowing and treatment 
Fig.1 Weekly average weather parameters at experiment site during October, 2015 to February, 2016

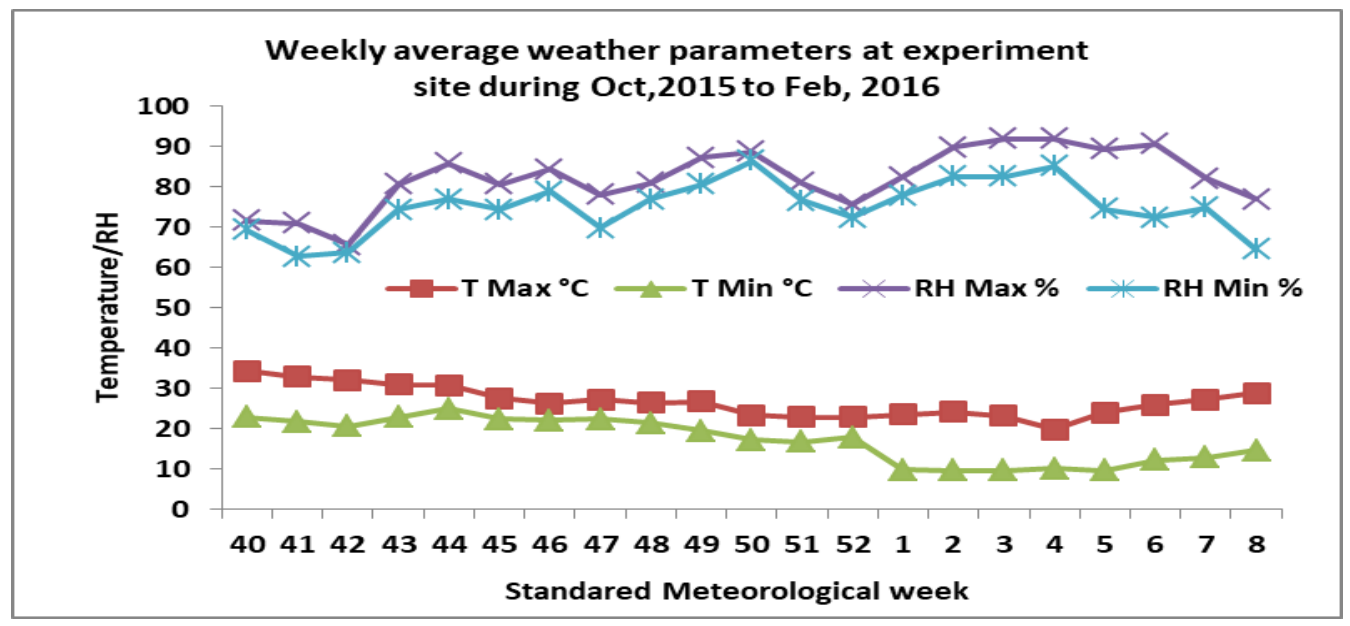

Fig.2 Relationship between times required for disease initiation and weather parameter

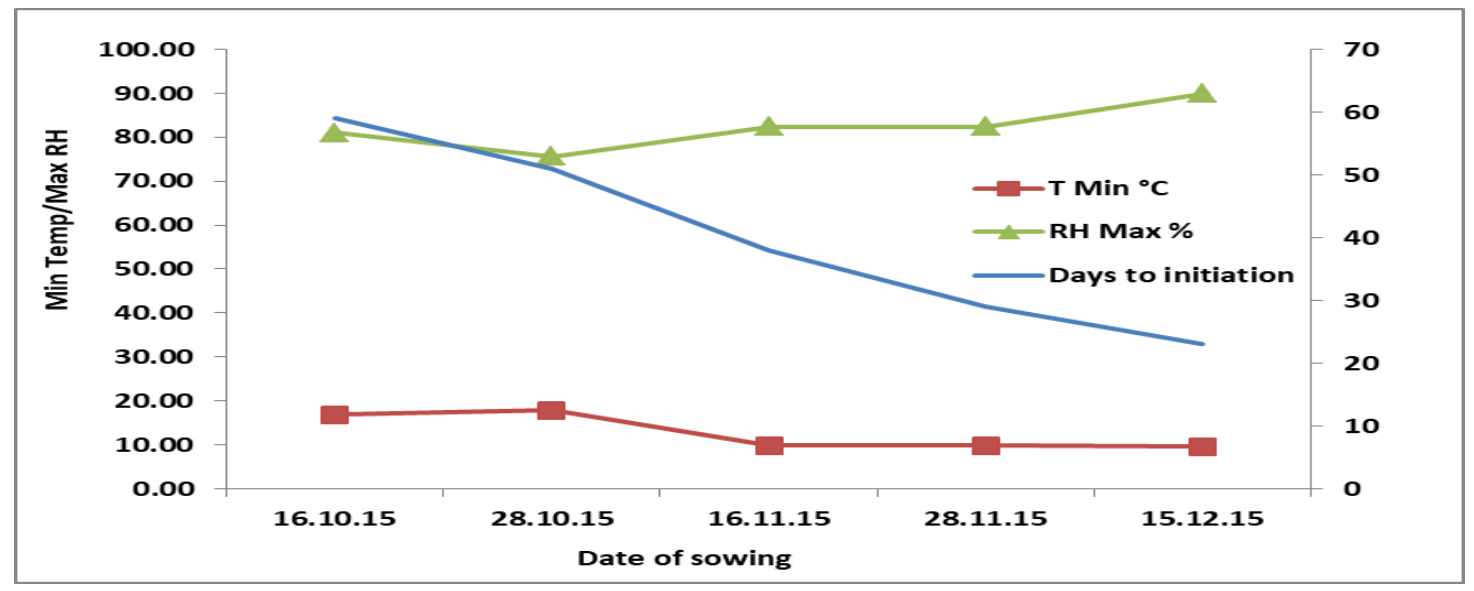

Fig.3 Relationship between weather parameters and days to disease initiation over combined date of sowing

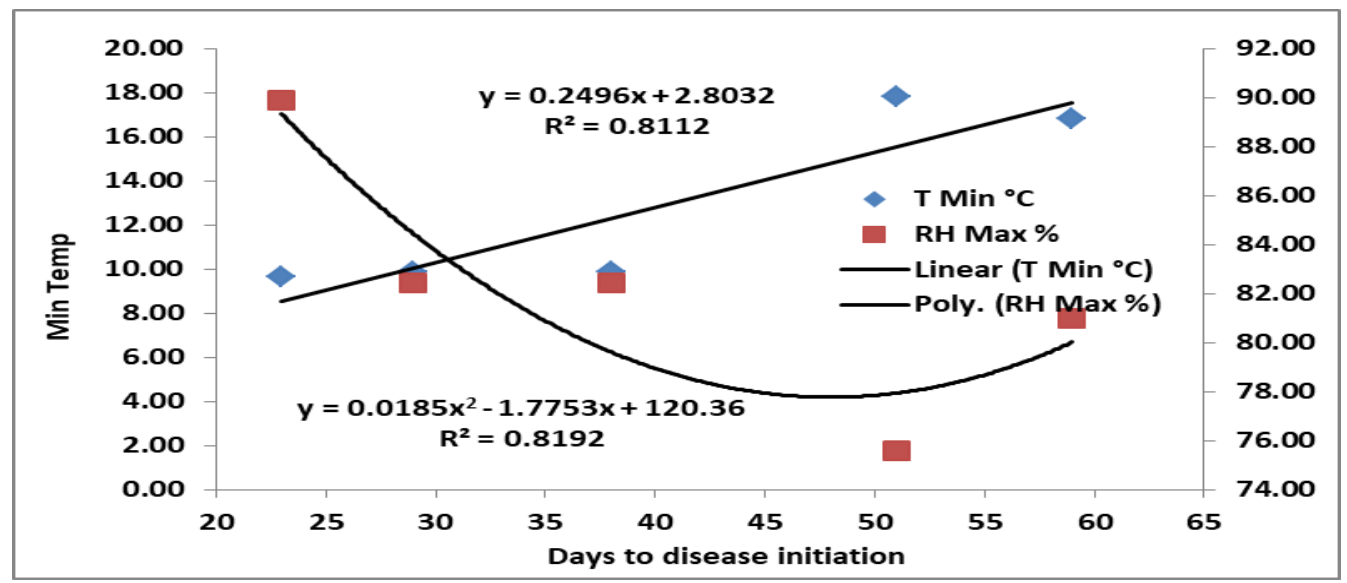


The experimental results are presented in table 1. It is observed that the late blight first appeared in control plots 7 days earlier than in the plots sprayed with mancozeb only but in the plots treated with systemic fungicides like Dithiocarbamate + mancozeb, cymoxanil + mancozeb and Ametoctradin + Dimithomorph, it appeared after 14 days of first appearance of the disease in control plots. Moreover, in control plots the per cent increase of late blight incidence was more in comparison to treated plots.

The results also revealed that in respect of per cent incidence of the disease (at 49 days after first appearance of symptoms) lowest disease was recorded in case of treatment $\mathrm{T} 3$ and total tuber yield i.e., in T3 it was 15.4 to 24.6 t/ha respectively followed by $\mathrm{T} 1$ and $\mathrm{T} 2$ as compared to control treatment (T5) where per cent disease incidence was 89.70 to $97.14 \%$ and total tuber yield was 8.68 to 14.0 t/ha. In case of the different dates of sowing the best result was observed in case of the treatment T3 where per cent incidence of the disease was 13.68 to $15.78 \%$ and total tuber yield was 15.4 to $24.6 \mathrm{t} / \mathrm{ha}$. These findings are also in line with earlier observation (De and Sengupta, 1988 and 1999) (Fig. 2).

The $2^{\text {nd }}$ best results was observed in case of treatments $\mathrm{T} 1$ where per cent incidence of the disease was 14.5 to $16.94 \%$ and total tuber yield was 14.67 to 23.33 t/ha. But statistically these two treatments were not significant. Therefore, it can be concluded that the severe late blight can effectively be controlled by adopting proper spray schedule like prophylactic spray with mancozeb @ $0.25 \%$ followed by Ametoctradin + Dimethomorph (a) $0.3 \%$ at the onset of the disease and 10 days after $1^{\text {st }}$ application followed by mancozeb@0.25\% seven days after the last application of systemic fungicide. These findings are also in line with Singh etal. (2001) who observed that in susceptible cultivars late blight can effectively be controlled if proper spray schedule is followed. Prophylactic spray with mancozeb @ $0.25 \%$ followed by Cymoxanil + mancozeb@0.3\% at the onset of the disease and 10 days after $1^{\text {st }}$ application followed by mancozeb@0.25\% seven days after the last application of systemic fungicide or prophylactic spray with mancozeb @ $0.25 \%$ followed by Dithiocarbamate + mancozeb @ $0.3 \%$ at the onset of the disease and 10 days after $1^{\text {st }}$ application followed by mancozeb @ $0.25 \%$ seven days after the last application of Dithiocarbamate + mancozeb. Similar type of observations were reported earlier against Phytophthora infestans in potato and tomato than either of them alone (Baider and Cohen, 2003).

Not only that the fungicide should be applied on community basis i.e. all the farmers in a locality should apply fungicide at the same time and the whole plant should be sprayed till run off.

\section{References}

Arora RK, Ahmad I and Singh BP (2012) Forecasting late blight of potato in Punjab using JHULSACAST model. Potato J 39(2): 173-76.

Baider A and Cohen Y (2003) Synergistic interaction between BABA and mancozeb in controlling Phytophthora infestans in potato and tomato and Pseudoperonospora cubensis in cucumber. Phytoparasitica 31(4): 399.

CIP. 1989. Fungal diseases of potato. International Potato Centre, Lima, Peru: $216 \mathrm{p}$.

Cooke LR, Schepers HTAM, Hermansen A, Bain RA, Bradshaw NJ, Ritchie F, Shaw DS, Evenhuis A, Kessel GJT, Wander JGN, Andersson B, Hansen JG, Hannukkala A, Naerstad R and Nielsen BJ (2011) Epidemiology and integrated 
control of potato late blight in Europe. Potato Res 54: 183-22.

Cooke, L.R., Schepers, H.T.A.M., Hermansen, A., Bain, R.A., Bradshaw, N.J., Ritchie, F., Shaw, D.S., Evenhuis, A., Kessel, G.J.T., Wander, J.G.N., Andersson, B., Hansen, J.G., Hannukkala A, Naerstad R and Nielsen BJ (2011) Epidemiology and integrated control of potato late blight in Europe. Potato Research. 54: 183-22.

De BK and Sengupta PC (1988) Studies on spray schedule of fungicide, against late blight disease of potato caused by Phytophthora infestans. Indian Agriculturist 32: 1-17

De BK and Sengupta PC (1991) Evaluation of fungicides against late blight disease of potato in plains of West Bengal. J Indian Potato Assoc 18: 176-77.

Dutta, B.L. 1979. Bacterial and Fungal Diseases of Potato. ICAR, New Delhi: 1-17.

Fry W (2008) Phytophthora infestans: the plant (and R gene) destroyer. Mol Plant Pathol 9(3): 385-02.

Johannes H (1953) Beitrag zur epidemiologie der Phytophthora infestans. (Contribution to the epidemiology of Phytophthora infestans. 1. Introduction and microclimatic studies). Zeit Pfianzenkrank Ua Pfianzenschutz 60: 289-07 (R.A.M. 33: 499, 1954).

Lozoya-Saldana H (2011) Evolution of vertical and horizontal resistance and its application in breeding resistance to potato late blight. Potato J 38(1): 1-8.

Singh BP and Bhat NM (2003) Emerging trends in the epidemiology of late blight of potato. Annu Rev Plant Pathol 2: 4383.

Singh BP, Ahamd I, Sharma VC and Shekhawat GS (2000) JHULSACAST: a computerized forecast of potato late blight in Western Uttar Pradesh. J Indian Potato Assoc 27(1-2): 25-34.

Singh BP, Singh PH, Gupta J and Singh L (2001). Integrated management of late blight under Shimla hills. J Indian Potato Assoc 28(1): 84-85.

Van Everdingen E (1926) The relation between weather conditions and potato blight, Phytophthora infestans (in Dutch) Tijdschr. Pfantenziekten. 32: 129-40.

Wallin JR and Hoyman WG (1954) Forecasting potato late blight in North Dakota. Dakota Agric Exp Stn Bimonth Bull 16: 226-31.

\section{How to cite this article:}

Hembram, S., R. Patsa, S. Baskey and Hansda, M. 2018. Effect of Weather Indices on Late Blight of Potato and Its Management in Northern District of West Bengal, India. Int.J.Curr.Microbiol.App.Sci. 7(09): 1737-1743. doi: https://doi.org/10.20546/ijcmas.2018.709.210 